Extension Scheme is to be held in Cambridge on July 9 and 10' Courses of lectures and practical work are to be arranged for students for local centres who are to reside in Cambridge during the month of August.

A very interesting report on the progress of the Extension movement by Dr. R. D. Roberts appears in the Cambridge University Reporter of May 27. The account he gives of the enthusiasm and energy displayed by certain of the Students' Associations attending Extension lectures is most encouraging, and shows how wide-spread is the influence for good exerted by the University in this connection.

\section{SCIENTIFIC SERIALS.}

THE Quarterly Tournal of Microscopical Science for April I89o contains papers on Phymosoma varians, Selenka, by Arthur E. Shipley (plates i. to iv.). The material for this paper was collected by Mr. Weldon in the Bahama Islands, where the species was fairly abundant in the soft coral rock. The general morphology and minute structure of this animal are described in great detail, and accompanied by some excellent illustrations ; the head of Phymosoma is surrounded by a stiffened vascular horseshoe-shaped lip, the dorsal ends of which are continuous with the ends of a hippocrepian lophophor, which bears a crown of about eighteen tentacles-the number being always even; between this lophophor and the vascular lip is the crescentiform opening of the mouth. The author would keep the genus Phoronis as a form closely allied to the more normal Gephyrea inermia, and compares the head of Phymosoma as seen from above with a view of Phoronis. - On the spinning apparatus of the geometric spiders, by C. Warburton (plate v.). Proves by a series of interesting experiments that a spider's line does not consist of many strands fused or woven together, but ordinarily of two or four distinct threads; the ground line of the spiral is double only, and the two strands are bound together merely by the viscid matter, which envelops them.-On the structure and functions of the cerata or dorsal papillæe in some Nudibranchiate Mollusca, by Prof. W. A. Herdman (plates vi. to x.). In some six gen era of British Nudibranchs examined, Herdman found that the dorsal papillæ, "cerata" of Lankester, were of two kinds-(I) those containing diverticula of the liver, as in the cases of Eolis and Doto, (2) those which were essentially but processes of the body-wall having no connection with the liver, as in Tritonia, Ancula, and Dendronotus. In Doris there are true branchiæ and no cerata. In Ancula both branchiæ and cerata are present. In Tritonia and Dendronotus there are cerata but no true branchiæ. In Doto and Eolis there are no true branchiæ. Morphologically all the forms of cerata are probably epipodial processes ; they are not of primary importance either in respiration or in digestion, but give to the animals, by their varied shape and colours, appearances which are in some cases protective and mimetic, and in others conspicuous and warning, as may be best suited to the individual surroundings and mode of life.-Further observations on the histology of striped muscle, by C. F. Marshall (plate xi.).-On Chætobranchus, a new genus of Oligochætous Chætopoda, by Dr. A. G. Bourne (plate xii.). This remarkable worm was found in the mud from a "tank" in Madras town; it is furnished with a remarkable series of branchial processes, dorso-laterally placed a pair to each of the anterior segments, commencing with the second segment; these processes completely surround a portion of the dorsal setæ bundles. The species has been named Chatobranchus semperi.-On the presence of Ranvier's constrictions in the spinal cord of Vertebrates, by Dr. W. T. Porter, of St. Louis (plate xii. bis). - A note to the editor from Prof. Buitschli, of Heidelberg, giving an account of his experimental imitation of protoplasmic movements. These protoplasma-like streaming properties of minute globules of a specially treated olive oil are of extreme interest.

American Fournal of Science, May 1890.-Experiments with a pendulum-electrometer, illustrating measurements of statical electricity in absolute units, by Alfred M. Mayer. The apparatus described affords an inexpensive and ready means of presenting clearly to a class the nature of measurements of statical electricity in absolute units; the instrument may be made to measure to the $\frac{1}{60}$ of a dyne, and a series of experiments are given to show that it gives the law of inverse squares, serves to determine the law of dissipation of an electric charge, and that it allows measures to be made of electrical distribution on conductors and the determination of quantity and potential. -On electric potential as measured by work, by the same author. A graphical illustration is given of the fact that in the case of two electrified spheres the potential function is a measure of work. - An elementary proof of the earth's rigidity, by Geo. F. Becker. It is proved that a simple strain spheroid affords an approximation to the deformation of an elastic globe sufficiently close to serve as a basis for Sir William Thomson's demonstration of the rigidity of the earth; the whole subject also being presented in a clear and elementary manner.--On the hornblende of St. Lawrence County, N.Y., and its gliding planes, by George $\mathrm{H}$. Williams. From the evidence brought forward it is concluded that an alteration of the symbols for the terminal planes of hornblende is necessary to show its analogy to pyroxene ; and that this change must be made in accordance with the assumption that the gliding plane, now called the orthodome $\mathrm{P}_{\infty}(\overline{\mathrm{I} O I})$ is the basal pinacoid $\mathrm{OP}(\mathrm{OOI})$ as suggested by Tschermak in 1884 . - Note on some secondary minerals of the amphibole and pyroxene groups, by Whitman Cross. In the course of the microscopical examination of some rocks from Custer County, Colorado, the author has observed two peculiar minerals of secondary origin, one an amphibole, and the other a pyroxene, and now describes their unusual properties, relationships, and mode of formation.--On spangolite, a new copper mineral, by S. L. Penfield. The specimen examined consisted of a rounded mass of impure cuprite mostly covered with hexagonal crystals of the new mineral. A full description of the habit, optical and physical properties, and chemical composition of the crystals is given.-Archran axes of Eastern North America, by James D. Dana. The partly or wholly Archæan ranges in New England and Canada parallel and to the east of the Appalachian protaxis are described, and the geological importance of the included troughs or basins pointed out.-On the metamorphic strata of South-Eastern New York by Frederick J. H. Merrill.-The radiant energy of a standard candle ; mass of meteors, by C. C. Hutchins. The whole radiant energy of the candle used was found to be $123 \times 10^{8}$ ergs per second, and the radiant energy of the visible part $2.46 \times 10^{6}$ ergs per second. The author also points out how such measures may be used to determine the mass of meteors. - Meteoric iron from North Carolina, by L. G. Eakins.-Distinctive characters of the order Hallopoda, by O. C. Marsh.-Additional characters of the Ceratopside, with notice of new Cretaceous Dinosaurs, by the same author.

Botanische Fahrbücher, von A. Engler, vol. xi., contains the following papers :-An essay on the biological relations of the flower of Aconitum, by Dr. M. Kronfeld. He states that Aconitum is an excellent example of a flower adapted to a certain insect, and that it is dependent upon Bombus for its fertilization, a fact which is further borne out by a comparison of the geographical area of the two, that of Aconitum being entirely covered by the area of distribution of Bombus. $\rightarrow$ Dr. O. Drude, on the principles of distinction of the formations of vegetation (Vegetationsformationen) as illustrated by the flora of Central Europe.-A description, by L. Wittmack, of the plants belonging to the Bromeliacea, collected by Herr F. C. Lehmann in Guatemala, Costarica, Columbia, and Ecuador.-A description of new species of Nyctaginaceæ, by Dr. A. Heimerl, with one plate.-A monographic sketch of the genus Helleborus, by Dr. V. Schiffner.-A contribution to the knowledge of the distribution of the Scotch fir in Northern Germany, in which it is stated that on the mainland it extends north of the Elbe as a native plant, only as far as a line connecting Rostock, Schwaan, Guistrow, Wittenburg, and Geesthacht ; in North-West Germany it is native only in the Upper Harz. - An anatomical investigation of the foliage leaves of the Arbutoideæ and Vaccinoideæ in relation to their systematic grouping, and geographical distribution leads Dr. Franz Niedenzu to the following conclusions: that the Arbuteæ are the oldest type, and of them more especially Arbutus and Arctous, while Arctostaphylos is more recent; the most recent group is the Thibandiece. These results are based upon details of the glandular and other hairs, of the teeth of the leaf, the epidermis and cuticle ( $130 \mathrm{pp}$. and 4 plates).- On the influence of the mean direction of the wind on the vegetation in the water, with references also to other phenomena of vegetation which depend upon the direction of the wind in the Western Baltic, by M. J. Klinge.-On a new Potentilla from Central America, by Dr. K. Fritsch.-Contributions to the knowledge of the Amaryllidaceæ, by Dr. F. Pax. - A list of the wild plants of the province of Wologda, by N. A. Ivanitzky.-On the

NO. IO74, VOL. 42] 
anatomical characters of the Hamamelidaceæ, examined with the object of using them as a basis for the systematic arrangement of the family, by A. Reinsch (I plate). - A list of the Polypodiaceæ. Gramineæ, Cyperacer, and Juncacere, collected by Dr. Marloth in South Africa.-On C.xsine domingensis Spr., by A. Garcke. - A treatise on the genus Platanus, with two plates, by J. Jankó. This paper has special reference to the detail characters of the leaf. - On two Soldanellas new to the flora of Hungary, by V. A. Richter.-At the end of the volume are abstracts of many recent memoirs published elsewhere, and a classified list of the most important works on systematic, geographical, and descriptive botany published in the year 1889.

Bulletin de la Société des Naturalistes de Moscou, 1889, No. 2. -On the origin of periodical comets, by Th. Bredichin (in French). The author examines into the cases of division of comets into two or more individuals, endeavouring to classify the better known ones into "families," and gives the formulæ for the cases when the impetus given to the corpuscles of a comet acted under a given angle to the plane of its motion.--Note on the genus Bonzbus, by General Radoszkowski (in French). -The Amphibian fauna of Europe: the Anura, by Dr. J. Bedriaga, being a full description (in German) of the two genera Rana and Bufo, their species, varieties, life, and geographical distribution.

No. 3.- On the modes of propagation of fresh-water fishes, by S. Nikitin (in French). M. Nikitin objects to the too hasty generalizations sometimes arrived at by men of science (especially with regard to Central Asia) as to the former communication between distant fluviatile basins and lakes which now have some species of fishes in common. He points out the possibility of the transport of the eggs of certain fishes by birds, and mentions the fact of young pikes, from six to ten centimetres long, being found in small. temporary ponds on the banks of the Moskva river, where they could by no means have migrated themselves. Further inquiry is asked for.-The transport of electrical energy, by $\mathrm{J}$. Weinberg (in German). - On the nesting of Podoces Panderi, by N. Zarudny. - The Amphibian fauna of Europe: the Anura (continued), by Dr. J. Bedriaga. The genera Hyla, Pelobatus, Pelodytes, Discoglossus, Bombinatur, and Alytes, are considered, and the author describes two new varieties of Hyla arborea under the names of var. orientalis and var. Molleri.On the influence of weather upon plants and animals, by Alex. Becker (in German).

\section{SOCIETIES AND ACADEMIES.}

\section{LONDON.}

Royal Society, May 8.-“Experiments on VapourDensity." By E. P. Perman, B.Sc. Communicated by Prof. Ramsay, F.R.S.

Vapour-density of Bromine.-This work was undertaken in order to see if the results of Prof. J. J. Thomson's experiments could be verified ; these appeared to show that bromine vapour dissociated on continued heating at a low pressure, and a comparatively low temperature. The method used was a modification of the Dumas method, by which a series of vapour-density determinations were made at different pressures, with the same identical material. The chief conclusions arrived at are (I) that no dissociation takes place at temperatures as high as $280^{\circ}$, and pressures as low as $20 \mathrm{~mm}$., even on continued heating; (2) that bromine vapour bas no tendency to form molecules with more than two atoms, on approaching the liquid state.

Vapour-density of Iodine. - The density of saturated iodine vapour was determined by an adaptation of Kundt's method of determining the velocity of sound in gases. The mean result was $126^{\circ}$, showing that liquid iodine has the formula $I_{2}$.

Induction Spark through Iodine Vapour. - The same apparatus was used as in finding the vapour-density of iodine. No alteration of the wave-length in the iodine vapour (as indicated by the heaps of finely-divided silica on the lower part of the tube) occurred on passing a series of sparks, and then causing the glass piston to vibrate. Sparking does not appear, therefore, to produce permanent dissociation of iodine vapour, notwithstand. ing the results pointing to a contrary conclusion, obtained by Prof. Thomson. Neither bromine nor iodine vapour, when saturated, threw the silica into heaps; it appears that soundwaves cannot be propagated in a saturated vapour, for condensation will be produced either by the waves of compression or those of expansion (according to the nature of the vapour, and its temperature) and the rates of propagation of the two sets of waves will therefore be different.

Vapour-densities of Sulphuric Anhydride, and Aqueous Hydrochloric Acid.-These were determined by the same method as the vapour-density of bromine. The vapour-density of sulphuric anhydride indicated a formula $\mathrm{SO}_{3}$, and that of aqueous hydrochloric acid showed that it is a mixture of molecules $\mathrm{HCl}$ and $\mathrm{H}_{2} \mathrm{O}$, and not a compound. In all these experiments the quantity of substance in the globe was not found by weighing but by estimating it volumetrically, portions being drawn off and absorbed in a suitable liquid. The globe was heated by means of a vapour-jacket; the vapours used were those of alcohol, chlorobenzene, bromohenzene, and bromonaphthalene.

The author is greatly indebted to Prof. Ramsay for constant advice and assistance in carrying out the work.

May 22.- "The Chemical Products of the Growth of Bacillus anthracis and their Physiological Action." By Sidney Martin, M.D., Pathologist to the Middlesex Hospital. Communicated by Dr. Klein, F.R.S.

The bacilli were grown in a solution of pure alkali-albumin (made from serum-proteids) and of mineral salts of the com position of the salts of the serum.

The cultivation of the bacilli was continued for ten to fifteen days, and the organisms removed by filtering through Chamberlain's filter. The filtrate contained the products of the bacterial growth, viz. :-

(1) Proto-albumose and deutero-albumose, and a trace of peptone: all with the same chemical reactions as the similar bodies formed in peptic digestion.

(2) An alkaloid.

(3) Small quantities of leucin and tyrosin.

The chief characteristic of the anthrax proto- and deuteroalbumose is their strong alkalinity in solution -an alkalinity not removed by absolute alcohol, by benzene, chloroform, or ether, or by prolonged dialysis. Acid-alcohol dissolves from the alkaline albumoses a trace of a poisonous body, but this is not in proportion to the toxicity of the albumoses. The albumoses are precipitated in an alkaline condition by saturation with $\mathrm{NaCl}$ (proto-albumose) or $\left(\mathrm{N} \mathrm{H}_{4}\right)_{2} \mathrm{SO}_{4}$. The alkaloid is soluble in absolute alcohol, amyl alcohol, and in water; insoluble in benzene, chloroform, and ether. It is strongly alkaline in solution, and a powerful base, readily forming salts with acids. The sulphate crystallizes in small needles or prisms; the oxalate in long, branching needles or flat plates. From the salts the alkaloid is easily regained. In solution, the alkaloid is precipitated by phosphotungstic, phosphomolybdic, and phosphoantimonic acids and platinic chloride, but not by potassio-mercuric iodide. It is slightly volatile, and, when kept exposed to the air, it becomes acid, and loses, to a great extent, its poisonous properties.

\section{Physiolooical Action.}

(I) The mixture of anthrax proto- and deutero-albumose is poisonous. In small doses it produces in mice a local subcuta. neous œdema, with some sluggishness, ending in recovery. Larger doses produce a greater œedema with more signs of illness, sluggishness leading to prolonged stupor, coma, and death in twenty-four hours or longer. A fatal dose for a mouse of 22 grams weight is 0.3 gram (subcutaneou ly injected). In some cases the spleen is enlarged: no organisms being present, as shown by gelatine tube cultivations. Boiling for a short time diminishes the toxicity of the proteid, but does not completely destroy it, and death may result from the boiled albumoses.

(2) The anthrax alkaloid produces symptoms and lesions similar to the albumoses, but much more rapidly and severely. The animal becomes ill directly after the injection, gradually becomes more and more sluggish, and dies in coma, or, if a non-lethal dose be given, it recovers from the state of stupor gradually. After denth, enormous local subcutaneous cedema is found, with congestion and sometimes thrombosis of the small veins. Peritoneal effusion is occasionally present, and the spleen is usually enlarged, dark, and congested, or simply congested without being greatly enlarged. The fatal dose for a mouse weighing 22 grams is between $O^{\prime} I$ and $O^{\prime} 15$ gram, death occurring in two to three hourst

The anthrax bacillus in digesting the alkali-albumin forms ( 1 ) proto-albumose, (2) deutero-albumose, (3) an alkaloid. The alkalinity of the albumoses may explain their toxic properties, being due to the fact that the alkaloid is in a "nascent" condition in the albumose molecule. The bacillus forms the alkaloid 